\title{
THE EFFECT OF AUDIT COMMITTEE EFFECTIVENESS ON CORPORATE GOVERNANCE: AN EMPIRICAL STUDY ON PUBLICLY LISTED COMPANIES IN INDONESIA
}

\author{
Judith T. Gallena*, Hamfri Djajadikerta and Amelia Setiawan \\ Faculty of Economics, Universitas Katolik Parahyangan \\ Jalan Ciumbuleuit No. 94, Bandung, Jawa Barat 40141, Indonesia \\ *judithgallena@yahoo.com
}

\begin{abstract}
An emerging country like Indonesia need a strong corporate governance in order for publicly listed companies to move forward and for its financial stability. This study explores the effect of audit effectiveness i.e. audit committee expertise, audit committee meetings, and audit committee independence on corporate governance. The population of this study is the awardees of most trusted, trusted, and fairly trusted companies for six consecutive years which the scores were based from Corporate Governance Perception Index (CGPI). The findings showed that the audit committee effectiveness significantly and positively affects corporate governance.
\end{abstract}

Keywords - Audit committee expertise; Audit committee meetings; Audit committee independence, awardeess; Corporate Governance Perception Index

\section{INTRODUCTION}

Indonesia's capital market prospect is increasing and at the same time is facing some challenges to be addressed to. Some of the prospects are, growing volume transactions followed by increasing domestic investor participation and strict market supervisory and broker internal control employed, paired with system enhancement to increase efficiency in the operation area, enforcing more robust operation for brokers. To mention some of the challenges, these are, the development of capital market derivatives products, and the development of retail market [1]. With all these prospects and challenges, and effective audit committee is needed and sound corporate governance must be implemented.

The fall of Enron and other giant companies reflects weak corporate governance and ineffective check and balances. The aftermath of Enron collapsed affected the confidence of all stakeholders especially the investors, government, and other regulatory bodies. The effect of this weak governance had prompted many countries to mandate corporate governance reform, this include Indonesia. After the incidents, corporate governance has become a serious issue [2]. Most investors believed that corporate governance is the process and structure used to direct and manage the business affairs of the company towards enhancing business prosperity and corporate accountability with the ultimate objective of realizing long-term shareholder value, whilst taking into account the interest of other stakeholders [3]. Business objectives were not achieved and investors were disappointed because of mismanagement. In an effort of Indonesia government to restore

Received: April 16, 2019

Reviewed: June 25, 2019

Accepted: July 15, 2019

* Corresponding Author 
back the trust of the investors, regulators and other interested parties, the government through the capital market authority in Indonesia known as Otoritas Jasa Keuangan-OJK (Financial Services Authority) functions as administering an integrated regulatory and supervisory system to all activities in the financial services sector [4]. The OJK is strictly monitoring the activities of publicly listed companies and rigorous supervision of day-today business transactions.

A sound governance is achieved when audit committee function well. Audit committee is considered as one of the factors that affect corporate governance. Audit committees play a crucial role in the financial reporting process of firms and have been the focus of corporate governance regulation in the wake of spectacular accounting scandals [5]. There are several countries like South Africa, United Kingdom (UK), Egypt and United States of America (USA) that had considered the role of audit committee on corporate governance especially if it is mandated. Unlike in Romania that Bucharest Stock Exchange is not aware of the significant role of the audit committee in corporate governance, unlike foreign companies, which understand the significant role of this structure [6].

The purpose of this study is to comprehend how audit committee effectiveness affects corporate governance, and at the same time, it aims to analyze the relation between audit committee effectiveness and corporate governance. The objects of the research are the publicly listed companies in Indonesia Stock Exchange. The uniqueness of this research is that the researcher specifically gathered data from all the listed companies that have received an award for six consecutive years (2011-2016) of being most trusted, trusted, and fairly trusted companies by Indonesia Institute of Corporate Governance (IICG).

\section{RUDIMENTARY AND HYPOTHESIS DEVELOPMENT}

\subsection{AN OVERVIEW OF INDONESIA CORPORATE GOVERNANCE AND AUDIT COMMITTEE}

Stakeholders of Enron, Parmalat, Worldcom and other companies suffer because of weak corporate governance. Most of the investors and other stakeholders lost their trust in capital market. The Asia Asset Management Event in 2004 emphasized on the need of Indonesia to improve corporate governance in order to attract foreign investors, and it the Code of Good Corporate Governance for Indonesia was published in January 2007 [7]. Previously, the capital market is controlled by Badan Pengawasan Pasar Modal (BAPEPAM) - Laporan Keuangan (Capital Market Supervisory Board- Financial Statements). In December 31, 2012, the function of Capital Market Supervisory Board Financial Statements was transferred to Otoritas Jasa Keuangan (Financial Services Authority) based on rule No.21 year 2011.

The Financial Services Authority (Otoritas Jasa Keuangan - OJK) is a State institution established under Law Number 21 Year 2011 which functions to organize an integrated regulatory and supervisory system for all activities within the financial services sector in the banking sector, capital market and non- banks such as Insurance, Pension Funds, Financing Institutions, and other Financial Services Institutions. In the early month of 2014, Otoritas Jasa Keuangan and International Finance Corporation (IFC) established Indonesia Corporate Governance Manual, which serves as a learning instrument to benchmark existing standards and practices in Indonesia with internationally recognized best practices. The Chairman of the Board of Commissioner said that "OJK believes that the Indonesia Corporate Governance Manual will benefit to all companies in Indonesia in developing their robust corporate governance practices" [8].

With the establishment of Indonesia Corporate Governance Manual, it served as benchmark for corporate governance practices in Indonesia to be more competitive, increase investor's confidence, reduce cost of capital, and can create a sustainable 
performance for every company specially the publicly listed companies. Aside from CG Manual, the Indonesia Institute of Corporate Governance (IICG) evaluates every year publicly listed companies, private companies, and government-owned companies in terms companies implementation of corporate governance. IICG provides scores in which SWA Magazine will publish the companies that are compliant with the criteria provided by IICG.

One of the factors that influence sound governance is audit committee. Audit committee in Indonesia is relatively new as it has only been regulated after the occurrence of the 1997 Asian financial crisis. In 2000, audit committee was initiated voluntarily, and then became mandatory in 2003 and amended in 2004 after the issuance of rules by Capital Market Supervisory Board (Badan Pengawasan Pasar Modal). It was stipulated in the rules that audit committee membership must comprise of at least three members, one of whom shall be an independent commissioner and concurrently the chairman of the audit committee, while the others shall be external independent parties. Additionally, at least one of the audit committee shall have accounting and/or finance expertise. The responsibility of the audit committee is to provide independent professional advice to the board of commissioners. In terms of international comparison, audit committee rules in Indonesia, in general, are similar to those in the USA [9].

\subsection{CORPORATE GOVERNANCE}

Corporate governance makes sure that the company is operating smoothly in accordance to what it purports to be. Corporate governance must be established in every entity in order to achieve business main target that is, profitability and the continuance of the business to operate. [10] said that "beginning with Adam Smith in 1776, expanded upon by Berle and Means (1932), and formalized by Jensen and Meckling (1976), an extensive literature has developed noting both the virtues and defects in the corporate governance process." Every company desires for good governance. Good corporate governance is about exhibiting ethical behaviour on all business dealings and also take good care of its employees' welfare by providing good working conditions and good salaries [11]. Good governance is all about behaving ethically in the corporate world.

Corporate governance refers to the way organizations are regulated and governed [11]. Corporate governance can raise many strategic and policy issues which might need the intervention of management [12]. Corporate governance is about the way power is exercised over corporate entities [13]. Corporate governance refers to the framework of rules, practices and processes that board of directors apply to direct and control their firm for ensuring accountability, fairness and transparency in a firm's relationship with all its stakeholders including its shareholders, management, customers, suppliers, financiers, government and the community [14]. Corporate governance is aimed at avoiding massive disasters before they occur. Following the 2002 introduction of the Sarbanes-Oxley Act in the United States, corporate governance has become a serious issue [2]. Corporate governance is the process and structure used to direct and manage the business affairs of the company towards enhancing business prosperity and corporate accountability with the ultimate objective of realizing long-term shareholder value, whilst taking into account the interest of other stakeholders [3].

Corporate governance structure is to organize and manage firms, which concern the relationships among the firm management, its board of directors, its shareholders and other stakeholders. A study conducted by [15] suggests corporate governance structure as "ways of bringing the interests of shareholders and managers into line and helping firms run for the benefit of shareholders, while [16] regards corporate governance structure as a monitoring mechanism to lessen the conflicts of interests among stakeholders by mitigating agency costs via to the separation between ownership and management as well as the majority of outside directors in the management board. Corporate governance is the 
set of actions and procedures that ensure a company is soundly managed so all investors receive a return on their investment that is reasonable given the risks involved [10].

Thus, corporate governance is ensuring the interest of stakeholders, including the shareholders and management. It is helping the company to govern in accordance with principles of good corporate governance.

\subsection{CORPORATE GOVERNANCE MEASUREMENT}

The Indonesia Institute of Corporate Governance (IICG) aims to become an independent and dignified institution that is central to the study of corporate governance development, as well as being a community partner in realizing the creation of sound business behaviors [17]. IICG was established as it originated from the economic crisis in 1998 in which there are a lot of companies who lack to practice the principles of good corporate governance. In order to materialize the aim of IICG, awards are given to the corporate governance compliers, and are evaluated based on the elements of CGPI. There are four (4) elements used by Indonesian Institute of Corporate Governance, these are:

a. Self-Assessment is an independent assessment by all organs, members, and stakeholders about the quality of Good Corporate Governance (GCG) implementation in the company. At this stage, the company fills out the questionnaire by inviting respondents to give the honest and objective perception in order to provide good feedback and evaluation to the company.

b. Documentation System is the stage of fulfillment of assessment requirements in the form submission of various documents that have been owned by the company related to the implementation of Good Corporate Governance (GCG).

c. Paper is a fulfillment of assessment requirements that describes a series of Good Corporate Governance (GCG) implementation processes and programs in the company. The paper created illustrates the direction and focus of the assessment in accordance with established systematic writing guidelines.

d. Observation is the final stage of assessment as an important part of Good Corporate Perception Index (GCPI) research and ranking process, which is a direct review to the company by the CGPI assessment team to ensure the quality of Good Corporate Governance (GCG) implementation obtained from data and information in all three stages.

The above elements are the criteria used by Indonesia Institute of Corporate Governance (IIGC). IIGC evaluates all the companies that are governance compliance. In the process of evaluation, there is a corresponding corporate governance score, which is called Corporate Governance Perception Index (CGPI) for each company being evaluated. The corresponding corporate governance perception indexes were ranked based on the category of Most Trusted, Trusted, and Fairly Trusted. The Corporate Governance Perception Index (CGPI) was categorized as follows:

Table I. Corporate Governance Perception Index (CGPI) and Award Category

\begin{tabular}{|c|c|c|}
\hline No. & CGPI Score (\%) & Award (Category) \\
\hline 1 & $85-100$ & Most Trusted \\
\hline 2 & $70-84$ & Trusted \\
\hline 3 & $65-69$ & Fairly Trusted \\
\hline
\end{tabular}


Table I above describes the category of the award given to the Publicly Listed Companies (PLCs). The scores were accumulated based on self- assessment, documentation, paper and observation.

\subsection{AUDIT COMMITTEE EFFECTIVENESS}

Audit committee is one on the governance mechanisms that monitors the welfare of the company. They function as control to every entity. There are several definitions for audit committee from different authors. According to [18] and [19], "An audit committee is as a delegate body of the board of directors charged with safeguarding and advancing the interests of shareholders. The audit committee has been considered as a very important monitoring mechanism of corporate governance for oversight of the company's financial reporting process [20]. In fact, the audit committee can improve the quality and accuracy of financial information [21,22], ensuring that the officers responsible for reporting and disclosure are more closely monitored and controlled.

An effective audit committee has qualified members with the authority and resources to protect stakeholder interests by ensuring reliable financial reporting, internal controls, and risk management through diligent oversight efforts [23]. Audit committee structure consist of audit committee expertise, audit committee meetings, and audit committee independence. Audit committee expertise is needed since the experts know how financial statements are being prepared, analyzed and interpreted. Audit committee meetings must be taken into consideration because discussions and decisions are made during the meeting. Meetings signify the diligence of the members to meet and discuss activities to be conducted. Lastly, audit committee members must be independent in order to maintain objectivity and unbiased opinion.

\subsection{AUDIT COMMITTEE EXPERTISE}

Expertise in financial matters a lot since it helps the audit committee members to visualize the real picture of company's financial situation. Members of the Audit Committee must be financially literate. An experienced individual who is a financial expert should chair the Audit Committee [8]. The presence of expert member in an audit committee began when scandals happened previous years. Following high profile corporate scandals in recent years, regulatory authorities worldwide, including South African policymakers, have reacted and mandated the inclusion of at least one financial expert in the audit committee: a member of accounting, auditing or finance background and/or experience. Such regulatory reforms have also called for all members of audit committees to be financially literate, with the assumption that the inclusion of financial experts in the audit committee ensures higher quality financial reporting [24, 25]. Academic research shows that presence of financial experts mitigates conflicts between management and external auditors; curbs well internal control weaknesses; results in positive capital market reactions; and enhances financial and non-financial disclosures [18, 26, 27, 28]. Majority of prior studies have documented a significant positive association between financial expertise and the quality of financial reporting [29, 18, 25] and non-financial disclosures [28]. However, [27] found insignificant relationship between financial expertise and non-financial disclosures of UK companies. [30] did not find a significant association between key aspects of the audit committee function such financial expertise and Integrated Reporting (IR) practice. [31] also added that AC expertise is positively associated with the quality firm's financial disclosure. The need to have at least one financial expert in the audit committee is assumed to be able to improve the effectiveness of the audit committee in carrying out supervisory duties [32]. Based on the above statements, the formulated hypothesis is as follows:

$H_{1}$ : Audit committee expertise has significant effect on corporate governance. 


\subsection{AUDIT COMMITTEE MEETINGS}

[33] said that "the number of meetings may reflect how proactive the audit committee is in assessing internal control". Regulators have often expressed a strong preference for an active audit committee that meets frequently during the year [34]). The audit committee should meet frequently and record its conclusions in discharging its duties and responsibilities [35]). [36] documented that the number of audit committee meetings is significantly associated with corporate reporting quality. In Egypt, [37] provide empirical evidence that the number of audit committee meetings contributes to the reduction of management reporting lag.

Audit committee authority and meetings are shown to have a significant positive impact on integrated reporting (IR) practice [30]. The frequency of audit committee meetings signals their desire to fulfill responsibilities [29]. A number of researchers argue that the frequency of audit committee meetings is an indication of committee activeness and by extension effectiveness [29, 23, 38]. For instance, [38] opine that audit committees which meet regularly shall have enough time to carry out their basic roles (e.g. monitoring) effectively. A number of empirical studies have documented a significant positive association between financial reporting quality and audit committee meetings [29, 38, [25]. Studies have also shown that the frequency of audit committee meetings has significant impact on non-financial disclosures [27,28]. However, other studies found no association between audit committee meetings and reporting quality [18, 39]. The meetings are shown to have a significant positive impact on Integrated Reporting practice [30]. The authors indicate that the number of AC meetings held during fiscal year is negatively associated with the quality of corporate disclosure [31].

The audit committee meeting or meeting serves as a medium to carry out the necessary improvements or evaluations, and includes ensuring the quality of the financial statements. Based on the decision of the Chairman of BAPEPAM Number Kep-29 / PM / 2004 Year 2004 in rule Number IX.I.5 stated that the audit committee held a meeting at least equal to the minimum requirement of board of commissioners meeting stipulated in the articles of association of the company. From the above explanation, the audit committee meeting is generally concluded to improve the quality of financial statements through its supervisory function and its suggestion which is especially expected to improve the timeliness of financial reporting. So based on the above statements, the formulated hypothesis is as follows:

\section{$\mathrm{H}_{2}$ : Audit committee meetings have significant effect on corporate governance.}

\subsection{AUDIT COMMITTEE INDEPENDENCE}

The independence of the audit committee function is one of the most important and emphasized aspects of audit committee in both academic research, as well as regulatory requirements $[29,40,41,42]$. The central thesis based on agency theory is that independent audit committees detect, or at least reduce, fraudulent reporting practices $[27,18,40,27]$ argue that the independence of audit committee enhances the quality and credibility of corporate reporting process, including non-financial disclosures. Also, [31] found out that audit committee (AC) independence is positively associated with Financial Reporting Quality (FRQ). The existence and the independence of audit committee are quite important for increasing the quality of information and providing exact information [43]. [8] elaborated that the member of the Audit Committee shall consist of 2 Independent Commissioner or any other external party. The independence of audit committee signals objectivity and impartiality. There is fairness when audit committee is independent. Thus the next hypothesis are as follows:

$H_{3}$ : Audit committee independence has significant effect on corporate governance. 
$H_{4}$ : Audit committee expertise, audit committee size, and audit committee independence have a significant effect on corporate governance.

\section{PROPOSED METHOD}

The method used in this study is an explanatory research. An explanatory research method is used in this study since it depicts causal relationship between variables. The object of this research is the publicly listed companies in Indonesia Stock Exchange. There are 199 firm year observations based on the recipient of trusted companies awarded by Indonesian Institute of Corporate Directors (IICD) for corporate governance category from 2011 to 2016. IICD evaluated the companies based on the four categories in scoring corporate governance, these are, self-assessment, document, paper, and observation. Out of 199 firm years, only 36 firm years were chosen based on the following criteria: The samples were drawn from the following criteria:

a. Listed companies in Indonesia Stock Exchange.

b. Recipient of award categorized as Most Trusted, Trusted, and Fairly Trusted. The companies are awarded by the Indonesian Institute for Corporate Governance and published in SWA Magazine from 2011 to 2016.

c. Recipient of award for six (6) consecutive years. The companies received the award categorized as Most Trusted, Trusted, and Fairly Trusted for six (6) year in a row. The awardees had maintained their status as compliers of Good Corporate Governance rules and procedures. The award given was based on Indonesia Institute of Corporate Governance (IICG) scores.

The independent variables are Audit Committee Expertise $\left(\mathrm{X}_{1}\right)$, Audit Committee Meetings $\left(\mathrm{X}_{2}\right)$, and Audit Committee Independence $\left(\mathrm{X}_{3}\right)$. Audit committee expertise is measured by the number of accounting or finance graduate among the members. Audit committee meetings is measured by the number meetings held in a year, while audit committee independence is measured through the number of independent members. These three (3) variables explain or influence the dependent variable. The dependent variable in this research is Corporate Governance ( $\mathrm{Y}$ ) which is measured through Corporate Governance Perception Index (CGPI).

\section{RESULTS AND ANALYSIS}

\subsection{AUDIT COMMITTEE EFFECTIVENESS AND CORPORATE GOVERNANCE}

It is known that audit committee was established to support corporate governance of every corporation. The audit committee is a committee established by the Board of Commissioners and serves as the supervisor of the performance of the board of directors in managing the company. Recognizing the importance of audit committee functions within an entity, the establishment of an audit committee is highly recommended for a company. In accordance with the regulations issued by Badan Pengawas Pasar Modal BAPEPAM (now handled by Otoritas Jasa Keuangan). Proper monitoring and supervision of audit committee on company's operations bring forth an added value to so called good corporate governance. The list of the companies or the object of the research is presented in Appendices A and B. As shown on Table II below, it describes the minimum, maximum, average, and standard deviation of audit committee expertise (ACE), audit committee meeting (ACM), audit committee independence (ACI), and corporate governance perception index (CGPI). 
Table II. Descriptive Statistics

\begin{tabular}{|l|c|c|c|c|c|}
\hline & N & Minimum & Maximum & Mean & Std. Deviation \\
\hline ACE & 36 & 1.00 & 4.00 & 2.2778 & 1.11127 \\
ACM & 36 & 12.00 & 72.00 & 34.6111 & 15.47953 \\
ACI & 36 & 1.00 & 7.00 & 3.4722 & 1.25325 \\
CGPI & 36 & 70.73 & 93.30 & 85.8967 & 4.70897 \\
Valid N (list wise) & & & & & \\
\hline
\end{tabular}

Based on Table II above, it shows that the average number of audit committee members that are expert in accounting and finance is two (2) while the maximum number of expert is four (4) and the minimum is one (1). A minimum of one (1) member is in accordance with regulations promulgated by the regulatory bodies, BAPEPAM. The audit committee is required to have at least one financial expertise in the audit committee assumed that the member will help improve the effectiveness of the audit committee in carrying out the supervisory function on the management side. In this study, the audit committee expertise is measured by the proportion of audit committee members who have expertise in the field of finance or accounting from formal education and had previous experience related to the financial aspects. As found by [19], that having at least one member of audit committee who has accounting or financial management experience reduced the likelihood of income-decreasing earning management and on the study made by [26] that audit committee increases financial disclosure. Disclosure is one of the aspects of transparency and transparency is one of the principles of corporate governance. All the listed companies in this study had comply the minimum required number of audit committee member that is expert.

The Table II above also shows the average number of meetings held by the audit committee which is 34.6 times or 35 times a year while the minimum is 12 times and the maximum is 72 times a year. In accordance with the regulations issued by [44], the audit committee is obliged to hold regular meetings at least once in 3 (three) months which means that at least the audit committee must conduct at least four meetings in one year. By conducting regular meetings, the audit committee is expected to improve the quality of supervision on the performance of the board of directors. All the listed companies in this study conducted the meetings more than the required number of meetings.

In addition, the Table II above showed an average of 3.47 or 4 audit committee members that are independent. The minimum number of audit committee members that are independent is 1 while the maximum number is 7 . As stipulated in GG manual, audit committee shall consist of 2 Independent Commissioner or any other external party. The average number exceeded the required number based on the regulation but then there is one company whose number of independent audit committee is below the stipulated rules. Lastly, the corporate governance perception index showed an average of $85.89 \%$, with a minimum of $70.73 \%$, and maximum of $93.30 \%$. This indicates that the listed companies in this study had garnered a score under the category of Trusted and Most Trusted.

\subsection{COEFFICIENT OF CORRELATION}

Based on the statistical analysis, the correlation coefficient of Audit Committee Expertise is 0.287, which means that the relationship between Audit Committee Expertise (ACE) and Corporate Governance is weak and directly related as shown on Table III below. 
Table III. AC Expertise Correlations

\begin{tabular}{|c|c|c|c|}
\hline & & $\mathrm{ACE}$ & CGPI \\
\hline \multirow{3}{*}{ ACE } & Pearson Correlation & 1 & .287 \\
\hline & Sig. (2-tailed) & & .089 \\
\hline & $\mathrm{N}$ & 36 & 36 \\
\hline \multirow{3}{*}{ CGPI } & Pearson Correlation & 287 & 1 \\
\hline & Sig. (2-tailed) & .089 & \\
\hline & $\mathrm{N}$ & 36 & 36 \\
\hline
\end{tabular}

The Table III above is an indication that inclusion of expert in accounting and finance in audit committee is related to corporate governance of the company even though it is weak. The correlation coefficient of Audit Committee Meetings (ACM) is -.282, which means that the relationship between Audit Committee Meeting (ACM) and Corporate Governance is weak and inversely related as shown in Table IV below.

Table IV. AC Meetings Correlations

\begin{tabular}{|c|c|c|c|}
\hline & & ACE & CGPI \\
\hline \multirow{3}{*}{$\mathrm{ACM}$} & Pearson Correlation & 1 & -.282 \\
\hline & Sig. (2-tailed) & & .096 \\
\hline & $\mathrm{N}$ & 36 & 36 \\
\hline \multirow{3}{*}{ CGPI } & Pearson Correlation & -.282 & 1 \\
\hline & Sig. (2-tailed) & .096 & \\
\hline & $\mathrm{N}$ & 36 & 36 \\
\hline
\end{tabular}

The Table IV above is an indication that meeting held by audit committee is related to corporate governance of the company even though it is weak. The correlation coefficient of Audit Committee Independence (ACI) is .626, which means that the relationship between Audit Committee Independence (ACI) and Corporate Governance is strong and directly related as shown in Table $\mathrm{V}$ below,

Table V. AC Independence Correlations

\begin{tabular}{|c|c|c|c|}
\hline & & ACE & CGPI \\
\hline \multirow{3}{*}{$\mathrm{ACI}$} & Pearson Correlation & 1 & $.626^{* *}$ \\
\hline & Sig. (2-tailed) & & .000 \\
\hline & $\mathrm{N}$ & 36 & 36 \\
\hline \multirow{3}{*}{ CGPI } & Pearson Correlation & $.626 * *$ & 1 \\
\hline & Sig. (2-tailed) & .000 & \\
\hline & $\mathrm{N}$ & 36 & 36 \\
\hline
\end{tabular}

The Table $\mathrm{V}$ above is an indication an independent audit committee member is strongly related to corporate governance of the company.

\subsection{COEFFICIENT OF DETERMINATION}

The Tables VI-IX below show the result of $\mathrm{R}^{2}$ is which 0.083 or $8.3 \%$ for Audit Committee Expertise (ACE); .079 or $7.9 \%$ for Audit Committee Meeting (ACM); and .392 or $39.20 \%$ for Audit Committee Independence (ACI). This indicates that $8.3 \%$, $7.9 \%$, and $39.20 \%$ is the contribution of ACE, ACM, and ACI to Corporate Governance respectively, the remaining balance is brought about by other factors not included in this research. 
Table VI. Model Summaryb

\begin{tabular}{|c|c|c|c|c|}
\hline Model & $\mathrm{R}$ & R Square & $\begin{array}{l}\text { Adjusted R } \\
\text { Square }\end{array}$ & $\begin{array}{l}\text { Std. Error of the } \\
\text { Estimate }\end{array}$ \\
\hline 1 & $.287^{\mathrm{a}}$ & .083 & .056 & 4.57627 \\
\hline
\end{tabular}

a. Predictors: (Constant), AC EXPERTISE

b. Dependent Variable: CGPI

Table VII. Model Summaryb

\begin{tabular}{|c|c|c|c|c|}
\hline Model & $\mathrm{R}$ & $\mathrm{R}$ Square & $\begin{array}{c}\text { Adjusted R } \\
\text { Square }\end{array}$ & $\begin{array}{c}\text { Std. Error of the } \\
\text { Estimate }\end{array}$ \\
\hline 1 & $.282^{\mathrm{a}}$ & .079 & .052 & 4.58421 \\
\hline
\end{tabular}

a. Predictors: (Constant), AC MEETINGS

b. Dependent Variable: CGPI

Table VIII. Model Summaryb

\begin{tabular}{|c|c|c|c|c|}
\hline Model & $\mathrm{R}$ & R Square & $\begin{array}{c}\text { Adjusted R } \\
\text { Square }\end{array}$ & $\begin{array}{c}\text { Std. Error of the } \\
\text { Estimate }\end{array}$ \\
\hline 1 & $.626^{\mathrm{a}}$ & .392 & .374 & 3.72607 \\
\hline
\end{tabular}

a. Predictors: (Constant), AC INDEPENDENCE

b. Dependent Variable: CGPI

For the overall result of coefficient determination, the $\mathrm{R}^{2}$ is .427 or $42.7 \%$ which means that the combined contribution of ACE, ACM, and ACI to CG in $42.70 \%$ and the remaining balance of $57.3 \%$ is due to other factors that is not included in this study.

Table IX. Model Summaryb

\begin{tabular}{|c|c|c|c|c|}
\hline Model & $\mathrm{R}$ & R Square & $\begin{array}{c}\text { Adjusted R } \\
\text { Square }\end{array}$ & $\begin{array}{c}\text { Std. Error of the } \\
\text { Estimate }\end{array}$ \\
\hline 1 & $.653^{\mathrm{a}}$ & .427 & .373 & 3.72834 \\
\hline
\end{tabular}
a. Predictors: (Constant), AC EXPERTISE, AC MEETINGS, AC INDEPENCE
b. Dependent Variable: CGPI

\subsection{HYPOTHESIS TESTING ON AUDIT EFFECTIVENESS ON CORPORATE GOVERNANCE}

In testing the hypothesis, a significance level of $0.05(\alpha=5 \%)$ is used to reject or to accept hypothesis previously mentioned. $\mathrm{H}_{1}, \mathrm{H}_{2}, \mathrm{H}_{3}$, and $\mathrm{H}_{4}$ is accepted if the probability significance $<$ significance level of 0.05 , otherwise rejected if the probability significance $>$ significance level of 0.05 . Based on the statistical result, audit committee expertise (ACE) significance is 0.211 and audit committee meeting (ACM) significance is 0.464 , it indicates that the result is higher than the significant level of 0.05 , and therefore $\mathrm{H}_{1}$ and $\mathrm{H}_{2}$ is rejected and $\mathrm{H}_{\mathrm{o}}$ is accepted, as expressed that audit committee expertise and audit committee meeting have no significant effect on corporate governance. Rejecting $\mathrm{H}_{1}$ means that audit committee expertise does not have effect because expertise may not be necessary for corporate governance as found by [27] that there is no significant relationship between financial expertise and non-financial disclosures. In addition, [30] did not find a significant association between key aspects of the audit committee function such financial expertise and Integrated Reporting (IR) practice. As long as the company is governed well by the board, audit committee expertise is not necessary. The same is through with audit committee meeting, too much meeting is not effective for good governance. [31] found that the number of AC meetings held during fiscal year is negatively associated with the quality of corporate disclosure. This means that the audit committee should not devote more of their time to meetings.

The significant result of ACI is 0.000 which means that it is below the 0.05 significant level and therefore $\mathrm{H}_{3}$ is accepted conveying that audit committee independence has significant effect on corporate governance. Audit committee is effective when the audit 
committee consist of independent members. An independent member is objective, not biased, and sees to it that the company is governed well. This finding is supported by $[29,19,40]$, that the central thesis based on agency theory is that independent audit committees detect, or at least reduce, fraudulent reporting practices). Fraudulent practices are present when corporate governance is weak. Table $\mathrm{X}$ shows the obtained significance result:

Table X. Coefficientsa

\begin{tabular}{|c|c|c|c|c|c|c|}
\hline \multirow{2}{*}{\multicolumn{2}{|c|}{ Model }} & \multicolumn{2}{|c|}{$\begin{array}{l}\text { Unstandardized } \\
\text { Coefficients }\end{array}$} & \multirow{2}{*}{$\begin{array}{c}\text { Standardized } \\
\text { Coefficients }\end{array}$} & \multirow[t]{2}{*}{$\mathrm{t}$} & \multirow[t]{2}{*}{ Sig. } \\
\hline & & B & Std. Error & & & \\
\hline \multirow{4}{*}{1} & (Constant) & 74.386 & 3.652 & & 20.371 & .000 \\
\hline & ACE & .746 & .585 & .176 & 1.275 & .211 \\
\hline & $\mathrm{ACM}$ & .037 & .049 & .120 & .741 & 464 \\
\hline & ACI & 2.462 & .607 & .655 & 4.056 & .000 \\
\hline
\end{tabular}

a. Dependent Variable: CGPI

Based on the Table $\mathrm{X}$ above, the multiple regression is as follows:

$$
\mathrm{CG}=74.386+0.746 \mathrm{ACE}+0.037 \mathrm{ACM}+2.462 \mathrm{ACI}
$$

The above value of regression conveys the following:

a. Corporate governance is constant with a value of 74.386 when it is not influenced by the variables of audit committee expertise, audit committee meetings, and audit committee independence.

b. Audit committee expertise, audit committee meetings, and audit committee independence directly affects corporate governance with the value $0.746,0.037$, and 2.462 respectively. This indicates that corporations are governed well when there are financial experts, conduct meetings regularly, and there are independent members in the company.

For the overall result of audit committee effectiveness on corporate governance, as shown in Table XI using the significance result is 0.000 which is lower than 0.05 significance level.

Table XI. ANOVAa

\begin{tabular}{|c|c|c|c|c|c|}
\hline Model & $\begin{array}{l}\text { Sum of } \\
\text { Squares }\end{array}$ & $\mathrm{df}$ & Mean Square & $\mathrm{F}$ & Sig. \\
\hline $\begin{array}{cc} & \text { Regression } \\
& \text { Residual } \\
\text { Total }\end{array}$ & $\begin{array}{l}331.288 \\
444.816 \\
776.105\end{array}$ & $\begin{array}{r}3 \\
32 \\
35\end{array}$ & $\begin{array}{r}110.429 \\
13.901\end{array}$ & 7.944 & $.000^{\mathrm{b}}$ \\
\hline
\end{tabular}

a. Dependent Variable: CGPI

b. Predictors: (Constant), AC EXPERTISE, AC MEETINGS, AC INDEPENDENCE

The result showed that the $\mathrm{H}_{4}$ is accepted conveying that audit committee expertise, audit committee meeting, and audit committee independence have significant effect on corporate governance if simultaneously tested. The result of the study recognizes how important the role of audit committee on corporate governance. Having one financial expert in the audit committee is assumed to be able to improve the effectiveness of audit committee in carrying out supervisory tasks especially tasks that are related to corporate governance. Meeting or meetings conducted by the audit committee will certainly be very useful as a medium to carry out the various improvements or evaluations the company needs including its company's governance. The effectiveness of audit committee on 
corporate governance is supported [5] that audit committees play a crucial role in the financial reporting process of firms and has been the focus of corporate governance regulation in the wake of spectacular accounting scandals.

\section{CONCLUSION}

A well governed corporation will surely move forward and have the ability to maintain financial stability. The presence of audit committee is one of the factors that support the implementation of corporate governance. Audit committee plays a vital role on corporate governance. It was mandated that audit committee must be established to act as a monitoring tool for the company's operations. Audit committee supports the implementation of corporate governance. Audit committee effectiveness overall result shows a significant and positive effect on corporate governance. With the presence of the combined three indicators of audit committee effectiveness, it thus improves corporate governance of Indonesia publicly listed companies. It was criticized that corporate governance is weak in Indonesia not until 2015 that a stronger regulatory framework plays a critical role in the enhancement of the corporate governance score in 2015 [45]. The effort of OJK had proven that corporate governance is getting better. All the listed companies in this study were compliant of corporate governance conducted by IICG. Based on the research result described, the researcher recommends to do evaluation further the audit committee expert functions and frequency of audit committee meetings. For further research, combine other variables affecting corporate governance, such as audit committee size, increase the number of samples, and conduct the research in other business sector.

\section{APPENDIX}

APPENDIX A - Total Population

Awardees Companies (2011-2016) Based on Corporate Governance Perception Index (CGPI) 2010 -2016

\begin{tabular}{|c|c|l|c|}
\hline No. & $\begin{array}{c}\text { Year } \\
\text { Awarded }\end{array}$ & \multicolumn{1}{|c|}{ Company Name } & $\begin{array}{c}\text { Total } \\
\text { Score }\end{array}$ \\
\hline 1 & 2011 & PT Aneka Tambang (Persero) Tbk & 86,15 \\
\hline 2 & 2011 & PT Bank CIMB Niaga Tbk & 91,46 \\
\hline 3 & 2011 & PT Bank Mandiri (Persero) Tbk & 91,81 \\
\hline 4 & 2011 & PT Bank Negara Indonesia (Persero) Tbk & 85,35 \\
\hline 5 & 2011 & PT Bank Tabungan Negara (Persero) Tbk & 85,70 \\
\hline 6 & 2011 & PT Garuda Indonesia (Persero) Tbk & 85,82 \\
\hline 7 & 2011 & PT Krakatau Steel (Persero) Tbk & 85,19 \\
\hline 8 & 2011 & PT Telekomunikasi Indonesia (Persero) Tbk & 89,10 \\
\hline 9 & 2011 & PT United Tractors Tbk & 87,36 \\
\hline 10 & 2011 & PT Adhi Karya (Persero) Tbk & 77,28 \\
\hline 11 & 2011 & PT Angkasa Pura II (Persero) & 77,67 \\
\hline 12 & 2011 & PT Astra Otoparts Tbk & 78,11 \\
\hline 13 & 2011 & PT Asuransi Jasa Indonesia (Persero) & 82,77 \\
\hline 14 & 2011 & PT Bakrie \& Brothers Tbk & 75,61 \\
\hline 15 & 2011 & PT Bakrie Telecom Tbk & 73,97 \\
\hline 16 & 2011 & PT Bakrieland Development Tbk & 77,36 \\
\hline 17 & 2011 & PT Bank DKI & 78,17 \\
\hline 18 & 2011 & PT BPD Jawa Barat \& Banten Tbk & 78,19 \\
\hline 19 & 2011 & PT Bukit Asam Persero & 84,33 \\
\hline 20 & 2011 & PT Bumi Resources Tbk & 70,83 \\
\hline 21 & 2011 & PT Indo Tambangraya Megah Tbk & 77,42 \\
\hline 22 & 2011 & PT Jamsostek (Persero) & 83,40 \\
\hline 23 & 2011 & PT Jasa Marga (Persero) Tbk & 83,41 \\
\hline 24 & 2011 & PT Kawasan Berikat Nusantara (Persero) & 74,69 \\
\hline 25 & 2011 & PT Kereta Api Indonesia (Persero) & 70,18 \\
\hline 26 & 2011 & PT Krakatau Bandar Samudera & 75,70 \\
\hline
\end{tabular}




\begin{tabular}{|c|c|c|c|}
\hline 27 & 2011 & PT Krakatau Engineering & 75,81 \\
\hline 28 & 2011 & PT Krakatau Industrial Estate Cilegon & 73,28 \\
\hline 29 & 2011 & PT Krakatau Tirta Industri & 72,28 \\
\hline 30 & 2011 & PT Panorama Transpostasi Tbk & 70,10 \\
\hline 31 & 2011 & PT Pertamina (Persero) & 76,93 \\
\hline 32 & 2011 & PT Timah (Persero) Tbk & 70,73 \\
\hline 33 & 2011 & PT. Wilayah Karya (Persero) Tbk & 79,90 \\
\hline 34 & 2012 & PT Aneka Tambang (Persero) Tbk & 86,55 \\
\hline 35 & 2012 & PT Bank CIMB Niaga Tbk & 89,88 \\
\hline 36 & 2012 & PT Bank Mandiri (Persero) Tbk & 91,91 \\
\hline 37 & 2012 & PT Bank Negara Indonesia (Persero) Tbk & 85,75 \\
\hline 38 & 2012 & PT Bank OCBC NISP Tbk & 85,86 \\
\hline 39 & 2012 & PT Bank Syariah Mandiri & 85,45 \\
\hline 40 & 2012 & PT Bank Tabungan Negara (Persero) Tbk & 85,90 \\
\hline 41 & 2012 & PT Garuda Indonesia (Persero) Tbk & 85,84 \\
\hline 42 & 2012 & PT Telekomunikasi Indonesia (Persero) Tbk & 89,57 \\
\hline 43 & 2012 & PT United Tractors Tbk & 87,77 \\
\hline 44 & 2012 & PT Adira Dinamika Multi Finance Tbk & 78,19 \\
\hline 45 & 2012 & PT Astra Honda Motor Tbk & 78,08 \\
\hline 46 & 2012 & PT Astra Otoparts Tbk & 79,09 \\
\hline 47 & 2012 & PT Asuransi Jasa Indonesia (Persero) & 83,05 \\
\hline 48 & 2012 & PT Bakrie \& Brothers Tbk & 76,23 \\
\hline 49 & 2012 & PT Bakrie Telecom Tbk & 75,73 \\
\hline 50 & 2012 & PT Bakrieland Development Tbk & 77,37 \\
\hline 51 & 2012 & PT Bank DKI & 80,24 \\
\hline 52 & 2012 & PT Bank Jateng & 78,55 \\
\hline 53 & 2012 & PT Bank Mutiara Tbk & 78,85 \\
\hline 54 & 2012 & PT Bank Nusantara Parahyangan Tbk & 79,94 \\
\hline 55 & 2012 & PT Bank Rakyat Indonesia (Persero) Tbk & 84,16 \\
\hline 56 & 2012 & PT BPD Jawa Barat Banten Tbk & 77,80 \\
\hline 57 & 2012 & PT Bukit Asam (Persero) Tbk & 82,55 \\
\hline 58 & 2012 & PT Bumi Resources Tbk & 72,80 \\
\hline 59 & 2012 & PT Indonesia Power & 80,53 \\
\hline 60 & 2012 & PT Jasa Marga (Persero) Tbk & 83,65 \\
\hline 61 & 2012 & PT Kawasan Berikat Nusantara (Persero) & 73,55 \\
\hline 62 & 2012 & PT Kereta Api Indonesia (Persero) & 71,23 \\
\hline 63 & 2012 & PT Krakatau Engineering & 77,87 \\
\hline 64 & 2012 & PT Krakatau Industrial Estate Cilegon & 75,57 \\
\hline 65 & 2012 & PT Krakatau Tirta Industri & 72,63 \\
\hline 66 & 2012 & PT Petrokimia Gresik & 80,04 \\
\hline 67 & 2012 & PT Sucofindo (Persero) & 79,23 \\
\hline 68 & 2012 & PT Timah (Persero) Tbk & 75,68 \\
\hline 69 & 2012 & PT Berau Coal & 65,94 \\
\hline 70 & 2012 & PT Metropolitan Land Tbk & 66,51 \\
\hline 71 & 2012 & PT Panorama Transportasi Tbk & 68,90 \\
\hline 72 & 2012 & PT Pelabuhan Indonesia II (Persero) & 69,92 \\
\hline 73 & 2012 & PT Pelabuhan Indonesia III (Persero) & 69,72 \\
\hline 74 & 2013 & PT Aneka Tambang (Persero) Tbk & 88,70 \\
\hline 75 & 2013 & PT Bank Cental Asia Tbk & 85,29 \\
\hline 76 & 2013 & PT Bank CIMB Niaga Tbk & 89,75 \\
\hline 77 & 2013 & PT Bank Mandiri (Persero) Tbk & 91,88 \\
\hline 78 & 2013 & PT Bank Negara Indonesia (Persero) Tbk & 86,06 \\
\hline 79 & 2013 & PT Bank OCBC NISP Tbk & 85,95 \\
\hline 80 & 2013 & PT Bank Rakyat Indonesia (Persero) Tbk & 85,56 \\
\hline 81 & 2013 & PT Bank Syariah Mandiri & 86,52 \\
\hline 82 & 2013 & PT Bank Tabungan Negara (Persero) Tbk & 85,43 \\
\hline 83 & 2013 & PT Garuda Indonesia (Persero) Tbk & 85,93 \\
\hline 84 & 2013 & PT Telekomunikasi Indonesia (Persero) Tbk & 90,58 \\
\hline 85 & 2013 & PT United Tractors Tbk & 85,01 \\
\hline 86 & 2013 & PT Adi Sarana Armada Tbk & 75,10 \\
\hline 87 & 2013 & PT Adira Dinamika Multi Finance Tbk & 79,24 \\
\hline 88 & 2013 & PT Angkasa Pura II (Persero) & 78,60 \\
\hline
\end{tabular}




\begin{tabular}{|c|c|c|c|}
\hline 89 & 2013 & PT Astra Otoparts Tbk & 80,03 \\
\hline 90 & 2013 & PT Asuransi Jasa Indonesia (Persero) & 83,84 \\
\hline 91 & 2013 & PT Bank DKI & 81,32 \\
\hline 92 & 2013 & PT Bank Permata Tbk & 81,82 \\
\hline 93 & 2013 & PT BPD Jateng & 79,45 \\
\hline 94 & 2013 & PT Federal International Finance & 76,55 \\
\hline 95 & 2013 & PT Indo Tambangraya Megah Tbk & 79,16 \\
\hline 96 & 2013 & PT Indonesia Power & 82,49 \\
\hline 97 & 2013 & PT Jamsostek (Persero) & 83,75 \\
\hline 98 & 2013 & PT Jasa Marga (Persero) Tbk & 84,53 \\
\hline 99 & 2013 & PT Kawasan Berikat Nusantara (Persero) & 74,61 \\
\hline 100 & 2013 & PT Krakatau Daya Listrik & 74,54 \\
\hline 101 & 2013 & PT Krakatau Engineering & 78,58 \\
\hline 102 & 2013 & PT Krakatau Industrial Estate Cilegon & 77,70 \\
\hline 103 & 2013 & PT Krakatau Tirta Industri & 74,24 \\
\hline 104 & 2013 & PT Panorama Transportasi Tbk & 70,12 \\
\hline 105 & 2013 & PT Pelabuhan Indonesia III (Persero) & 70,71 \\
\hline 106 & 2013 & PT Pembangkitan Jawa Bali & 82,13 \\
\hline 107 & 2013 & PT Pertamina (Persero) & 80,16 \\
\hline 108 & 2013 & PT Pos Indonesia (Persero) & 76,59 \\
\hline 109 & 2013 & PT Tambang Batubara Bukit Asam (Persero) Tbk & 83,80 \\
\hline 110 & 2013 & PT Timah (Persero) Tbk & 77,81 \\
\hline 111 & 2013 & PT Wijaya Karya (Persero) Tbk & 80,36 \\
\hline 112 & 2013 & PT Bakrie \& Brothers Tbk & 69,22 \\
\hline 113 & 2013 & PT Bakrie Telecom Tbk & 68,96 \\
\hline 114 & 2013 & PT Bakrieland Development Tbk & 67,39 \\
\hline 115 & 2013 & PT Metropolitan Land Tbk & 67,55 \\
\hline 116 & 2014 & PT Aneka Tambang (Persero) Tbk & 88,92 \\
\hline 117 & 2014 & PT Asuransi Jasa Indonesia (Persero) & 85,04 \\
\hline 118 & 2014 & PT Bank Cental Asia Tbk & 86,06 \\
\hline 119 & 2014 & PT Bank Mandiri (Persero) Tbk & 92,36 \\
\hline 120 & 2014 & PT Bank Negara Indonesia (Persero) Tbk & 87,19 \\
\hline 121 & 2014 & PT Bank OCBC NISP Tbk & 86,17 \\
\hline 122 & 2014 & PT Bank Rakyat Indonesia (Persero) Tbk & 86,43 \\
\hline 123 & 2014 & PT Bank Syariah Mandiri & 86,55 \\
\hline 124 & 2014 & PT Garuda Indonesia (Persero) Tbk & 85,40 \\
\hline 125 & 2014 & PT Jasa Marga (Persero) Tbk & 85,16 \\
\hline 126 & 2014 & PT Telekomunikasi Indonesia (Persero) Tbk & 90,66 \\
\hline 127 & 2014 & PT Adi Sarana Armada Tbk & 77,03 \\
\hline 128 & 2014 & PT Angkasa Pura II (Persero) & 80,51 \\
\hline 129 & 2014 & PT Bank DKI & 81,93 \\
\hline 130 & 2014 & PT Bank Papua & 79,45 \\
\hline 131 & 2014 & PT Bank Permata Tbk & 81,71 \\
\hline 132 & 2014 & PT Bank Sinar Harapan Bali & 76,27 \\
\hline 133 & 2014 & PT Bank Tabungan Negara (Persero) Tbk & 84,94 \\
\hline 134 & 2014 & PT Bukit Asam (Persero) Tbk & 84,09 \\
\hline 135 & 2014 & PT Indo Tambangraya Megah Tbk & 80,13 \\
\hline 136 & 2014 & PT Kereta Api Indonesia (Persero) & 78,59 \\
\hline 137 & 2014 & PT Krakatau Engineering & 79,41 \\
\hline 138 & 2014 & PT Krakatau Industrial Estate Cilegon & 78,67 \\
\hline 139 & 2014 & PT Krakatau Tirta Industri & 76,26 \\
\hline 140 & 2014 & PT Mandiri Tunas Finance & 75,62 \\
\hline 141 & 2014 & PT Pelabuhan Indonesia III (Persero) & 74,28 \\
\hline 142 & 2014 & PT Pembangkitan Jawa Bali & 83,11 \\
\hline 143 & 2014 & PT Pertamina (Persero) & 81,22 \\
\hline 144 & 2014 & PT Petrokimia Gresik & 80,74 \\
\hline 145 & 2014 & PT Timah (Persero) Tbk & 80,10 \\
\hline 146 & 2014 & PT Bakrie Telecom Tbk & 66,44 \\
\hline 147 & 2015 & PT Aneka Tambang (Persero) Tbk & 89,12 \\
\hline 148 & 2015 & PT Asuransi Jasa Indonesia (Persero) & 85,32 \\
\hline 149 & 2015 & PT Bank Cental Asia Tbk & 86,59 \\
\hline 150 & 2015 & PT Bank Mandiri (Persero) Tbk & 92,88 \\
\hline
\end{tabular}




\begin{tabular}{|c|c|c|c|}
\hline 151 & 2015 & PT Bank Negara Indonesia (Persero) Tbk & 87,46 \\
\hline 152 & 2015 & PT Bank Rakyat Indonesia (Persero) Tbk & 86,90 \\
\hline 153 & 2015 & PT Bank Syariah Mandiri & 85,62 \\
\hline 154 & 2015 & PT Bank Tabungan Negara (Persero) Tbk & 85,75 \\
\hline 155 & 2015 & PT Bukit Asam (Persero) Tbk & 85,25 \\
\hline 156 & 2015 & PT Jasa Marga (Persero) Tbk & 85,47 \\
\hline 157 & 2015 & PT Bank OCBC NISP Tbk & 86,52 \\
\hline 158 & 2015 & PT Bank Mandiri Taspen Pos & 78,92 \\
\hline 159 & 2015 & PT Kereta Api Indonesia (Persero) & 80,35 \\
\hline 160 & 2015 & PT Krakatau Engineering & 80,25 \\
\hline 161 & 2015 & PT Krakatau Industrial Estate Cilegon & 79,43 \\
\hline 162 & 2015 & PT Krakatau Tirta Industri & 77,27 \\
\hline 163 & 2015 & PT Mandiri Sekuritas & 77,81 \\
\hline 164 & 2015 & PT Mandiri Tunas Finance & 78,13 \\
\hline 165 & 2015 & PT Pelabuhan Indonesia III (Persero) & 77,27 \\
\hline 166 & 2015 & PT Petrokimia Gresik & 81,65 \\
\hline 167 & 2015 & PT Timah (Persero) Tbk & 81,70 \\
\hline 168 & 2015 & PT Wijaya Karya (Persero) Tbk & 81,68 \\
\hline 169 & 2015 & PT Bakrie \& Brothers Tbk & 69,75 \\
\hline 170 & 2016 & PT Aneka Tambang (Persero) Tbk & 88,64 \\
\hline 171 & 2016 & PT Asuransi Jasa Indonesia (Persero) & 85,80 \\
\hline 172 & 2016 & PT Bank Central Asia (Persero) Tbk & 87,20 \\
\hline 173 & 2016 & PT Bank Mandiri (Persero) Tbk & 93,30 \\
\hline 174 & 2016 & PT Bank Negara Indonesia (Persero) Tbk & 87,74 \\
\hline 175 & 2016 & PT Bank OCBC NISP Tbk & 86,85 \\
\hline 176 & 2016 & PT Bank Rakyat Indonesia (Persero) Tbk & 87,74 \\
\hline 177 & 2016 & PT Bank Syariah Mandiri & 86,33 \\
\hline 178 & 2016 & PT Bank Tabungan Negara (Persero) & 86,59 \\
\hline 179 & 2016 & PT Bukit Asam (Persero) Tbk & 85,54 \\
\hline 180 & 2016 & PT Jasa Marga (Persero) Tbk & 85,81 \\
\hline 181 & 2016 & PT Telekomunikasi Indonesia (Persero) Tbk & 91,18 \\
\hline 182 & 2016 & PT Asuransi Jiwa Inhealth Indonesia (Mandiri Inhealth) & 71,99 \\
\hline 183 & 2016 & PT Axa Mandiri Financial Services & 72,47 \\
\hline 184 & 2016 & PT Bakrie \& Brothers Tbk & 72,68 \\
\hline 185 & 2016 & PT Bank DKI & 82,08 \\
\hline 186 & 2016 & PT Bank Mandiri Taspen Pos & 80,77 \\
\hline 187 & 2016 & PT Bank Pembangunan Daerah Riau Kepri & 73,49 \\
\hline 188 & 2016 & PT Bank Pembangungan Daerah Jawa Barat \& Banten Tbk & 82,13 \\
\hline 189 & 2016 & PT Bank Permata Tbk & 81,60 \\
\hline 190 & 2016 & PT BNI Syariah & 83,90 \\
\hline 191 & 2016 & PT Indonesia Power & 82,94 \\
\hline 192 & 2016 & PT Krakatau Tirta Industri & 78,44 \\
\hline 193 & 2016 & PT Mandiri Axa General Insurance & 72,61 \\
\hline 194 & 2016 & PT Mandiri Manajemen Investasi & 71,93 \\
\hline 195 & 2016 & PT Mandiri Sekuritas & 78,88 \\
\hline 196 & 2016 & PT Mandiri Tunas Finance & 78,79 \\
\hline 197 & 2016 & PT Pertamina (Persero) & 83,90 \\
\hline 198 & 2016 & PT Semen Indonesia (Persero) Tbk & 83,60 \\
\hline 199 & 2016 & PT Timah (Persero) Tbk & 82,15 \\
\hline
\end{tabular}

APPENDIX B - Total Sample (Six Consecutive Year)

\begin{tabular}{|c|c|c|l|c|}
\hline No. & $\begin{array}{c}\text { Year of } \\
\text { CGPI }\end{array}$ & $\begin{array}{c}\text { Year } \\
\text { Awarded }\end{array}$ & Name of Company & $\begin{array}{c}\text { Total } \\
\text { Score }\end{array}$ \\
\hline 1 & 2010 & 2011 & PT Aneka Tambang (Persero) Tbk & 86,15 \\
\hline 2 & 2011 & 2012 & PT Aneka Tambang (Persero) Tbk & 86,55 \\
\hline 3 & 2012 & 2013 & PT Aneka Tambang (Persero) Tbk & 88,70 \\
\hline 4 & 2013 & 2014 & PT Aneka Tambang (Persero) Tbk & 88,92 \\
\hline 5 & 2014 & 2015 & PT Aneka Tambang (Persero) Tbk & 89,12 \\
\hline 6 & 2015 & 2016 & PT Aneka Tambang (Persero) Tbk & 88,64 \\
\hline 7 & 2010 & 2011 & PT Asuransi Jasa Indonesia (Persero) & 82,77 \\
\hline 8 & 2011 & 2012 & PT Asuransi Jasa Indonesia (Persero) & 83,05 \\
\hline
\end{tabular}




\begin{tabular}{|c|c|l|l|c|}
\hline 9 & 2012 & 2013 & PT Asuransi Jasa Indonesia (Persero) & 83,84 \\
\hline 10 & 2013 & 2014 & PT Asuransi Jasa Indonesia (Persero) & 85,04 \\
\hline 11 & 2014 & 2015 & PT Asuransi Jasa Indonesia (Persero) & 85,32 \\
\hline 12 & 2015 & 2016 & PT Asuransi Jasa Indonesia (Persero) & 85,80 \\
\hline 13 & 2010 & 2011 & PT Bank Mandiri (Persero) Tbk & 91,81 \\
\hline 14 & 2011 & 2012 & PT Bank Mandiri (Persero) Tbk & 91,91 \\
\hline 15 & 2012 & 2013 & PT Bank Mandiri (Persero) Tbk & 91,88 \\
\hline 16 & 2013 & 2014 & PT Bank Mandiri (Persero) Tbk & 92,36 \\
\hline 17 & 2014 & 2015 & PT Bank Mandiri (Persero) Tbk & 92,88 \\
\hline 18 & 2015 & 2016 & PT Bank Mandiri (Persero) Tbk & 93,30 \\
\hline 19 & 2010 & 2011 & PT Bank Negara Indonesia (Persero) Tbk & 85,35 \\
\hline 20 & 2011 & 2012 & PT Bank Negara Indonesia (Persero) Tbk & 85,75 \\
\hline 21 & 2012 & 2013 & PT Bank Negara Indonesia (Persero) Tbk & 86,06 \\
\hline 22 & 2013 & 2014 & PT Bank Negara Indonesia (Persero) Tbk & 87,19 \\
\hline 23 & 2014 & 2015 & PT Bank Negara Indonesia (Persero) Tbk & 87,46 \\
\hline 24 & 2015 & 2016 & PT Bank Negara Indonesia (Persero) Tbk & 87,74 \\
\hline 25 & 2010 & 2011 & PT Bank Tabungan Negara (Persero) Tbk & 85,70 \\
\hline 26 & 2011 & 2012 & PT Bank Tabungan Negara (Persero) Tbk & 85,90 \\
\hline 27 & 2012 & 2013 & PT Bank Tabungan Negara (Persero) Tbk & 85,43 \\
\hline 28 & 2013 & 2014 & PT Bank Tabungan Negara (Persero) Tbk & 84,94 \\
\hline 29 & 2014 & 2015 & PT Bank Tabungan Negara (Persero) Tbk & 85,75 \\
\hline 30 & 2015 & 2016 & PT Bank Tabungan Negara (Persero) & 86,59 \\
\hline 31 & 2010 & 2011 & PT Jasa Marga (Persero) Tbk & 83,41 \\
\hline 32 & 2011 & 2012 & PT Jasa Marga (Persero) Tbk & 83,65 \\
\hline 33 & 2012 & 2013 & PT Jasa Marga (Persero) Tbk & 84,53 \\
\hline 34 & 2013 & 2014 & PT Jasa Marga (Persero) Tbk & 85,16 \\
\hline 35 & 2014 & 2015 & PT Jasa Marga (Persero) Tbk & 85,47 \\
\hline 36 & 2015 & 2016 & PT Jasa Marga (Persero) Tbk & 85,81 \\
\hline & & & & \\
\hline
\end{tabular}

\section{REFERENCES}

[1] www.asiasecuritiesforum.org. (Retrieved 27, August 2017).

[2] B. Ameer, "Corporate Governance- Issues and Challenges in Pakistan." International Journal of Academic Research in Business and Social Sciences, vol. 3, no. 4, (2013), pp. 79-96.

[3] K. Keasey, S. Thompson and M. Wright, "Introduction: the corporate governance problem -competing diagnoses and solutions'. Corporate Governance: Economic and Financial Issues, Oxford University Press, Oxford, (1997), pp. 1-17.

[4] www.ojk.go.id. FAQ Otoritas Jasa Keuangan. (Retrieved, 03 December 2017).

[5] N. Chandar, H. Chang and X. Zheng,"Does overlapping membership on audit and compensation committees improve a firm's financial reporting quality?", Review of Accounting and Finance, vol. 11, no.2, (2012), pp.141-165.

[6] A.R. Crisan and M.T. Fülöp, "The role of the audit committee in corporate governance - case study for a sample of companies listed on BSE and the London Stock Exchange - FTSE 100". Procedia Economics and Finance vol. 5, (2014), pp. 1033 - 1041.

[7] J. Solomon, "Corporate Governance and Accountability, Third Edition, John Wiley \& Sons Ltd, The Atrium, Southern Gate, Chichester, West Sussex, PO19 8SQ, United Kingdom, (2010), pp.222.

[8] CG Manual, “The Indonesia Corporate Governance Manual”, First Edition, Jakarta, (2014).

[9] S. R. Ika and N.A. M. Ghazali, "Audit committee effectiveness and timeliness of reporting: Indonesian evidence", Managerial Auditing Journal, vol. 27, no. 4, (2012), pp. 403 - 424.

[10] S. M. Hennessey, "Corporate Governance Mechanisms in Action: The Case Of Air Canada" In Corporate Governance, vol. 11, (2005), pp.127-166.

[11] P. Zvavahera, and G.R. Ndoda, "Corporate governance and ethical behavior: The case of the Zimbabwe Broadcasting Corporation", Journal of Academic and Business Ethics, vol. 9, (2014), pp.1-8.

[12] J.W. Lorsch, "Harvard Business Review on Corporate Governance", Harvard Business School Press, (2000).

[13] V. Indermun and M.S. Bayat, "A Focus on Corporate Governance and the Relationship with Business", Business and Economics Journal, vol. 6, no. 1, (2015), pp. 1-8.

[14] A. Cadbury, "The corporate governance agenda", Corporate Governance:An International Review, Vol. 8 , no. 1, (2000), pp.7-15. 
[15] F. Mayer, "Corporate Governance, Competition and Performance. In Enterprise and Community: New Directions in Corporate Governance", Wiley, Oxford, (1997), pp: 176.

[16] A. Cadbury, "The Cadbury Committee Reports: Financial Aspects of Corporate Governance", First Published, Burgess Science Press, London, (1992).

[17] www.iicg.co.

[18] J. Bedard, S.M. Chtourou and L. Corteau, "The effect of audit committee expertise, independence, and activity on aggressive earning management", Auditing: A Journal of Practice \& Theory, vol. 23, no. 2, (2004). pp. 13-35.

[19] A. Klein "Audit committee, board of director characteristics, and earnings management", Journal of Accounting and Economics, Vol. 33 No. 3, (2002), pp. 375-400.

[20] P. L. Joshi and A. Wakil, "A study of the audit committees' functioning in Bahrain empirical findings", Managerial Auditing Journal, vol. 19, no.7, (2004), pp. 832-858.

[21] M. L. DeFond and J. Jiambalvo, "Incidence and circumstances of accounting errors", The Accounting Review, vol. 66, no. 3, (1991), pp. 643-655.

[22] D.A. McMullen,. "Audit committee performance: an investigation of the consequences associated with audit committees", Auditing: A Journal of Practice and Theory, vol. 15, no. 1, (1996) pp. 87-103.

[23] T. DeZoort, D. Hermanson, D. Archambeault and S. Reed, "Audit committee effectiveness: a synthesis of the empirical audit committee literature", Journal of Accounting Literature, vol. 21, (2002), pp. 3875.

[24] M. L. Defond, R. N. Hann R. N. and, X. Hu, "Does the market value financial expertise on audit committees of boards of directors?", Journal of Accounting Research, vol. 43, no. 2, (2005), pp. $153-193$.

[25] W.S. Kang, A. Kilgore and S. Wright, "The effectiveness of audit committees for low- and mid-cap firms”, Managerial Auditing Journal, vol. 26, no. 7, (2011), pp. 623-650.

[26] M. Mangena and R. Pike, "The effect of audit committee, shareholding, financial expertise, and size on interim financial disclosure", Accounting \& Business Research, vol. 35, no. 4, (2005), pp. 327-49.

[27] J. Li, M. Mangena and R. Pike, "The effect of audit committee characteristics on intellectual capital disclosure", The British Accounting Review, vol. 44, no.2, (2012), pp. 98-110.

[28] A. Ahmed Haji, "The role of audit committee attributes in intellectual capital disclosures: evidence from Malaysia”, Managerial Auditing Journal, vol. 30, nos. 8/9, (2015), pp. 756-784.

[29] L. J. Abbott, Y. Park and S. Parker, "The effects of audit committee activity and independence on corporate fraud", Managerial Finance, vol. 26, no. 11, (2000), pp. 55-67.

[30] A. Ahmed Haji and M. Anifowose, "Audit committee and integrated reporting practice: does internal assurance matter?", Managerial Auditing Journal, vol. 31, no. 8/9, (2016), pp. 915 - 948.

[31] M. Salehi and M. Shirazi, "Audit committee impact on the quality of financial reporting and disclosure Evidence from the Tehran Stock Exchange," Management Research Review, vol. 39, no. 12, (2016), pp. $1639-1662$.

[32] Bapepam-LK, Peraturan Nomor IX.I.5 tentang Pembentukan dan Pedoman Pelaksanaan Kerja Komite Audit (Lampiran dari Keputusan Ketua Bapepam Nomor Kep-29/PM/2004). Jakarta: Bapepam-LK, (2004).

[33] J. Krishnan, "Audit committee and internal control: an empirical analysis", The Accounting Review, vol. 80 , no. 2, (2005). pp. 649-675.

[34] A. Barua, D. Rama and V. Sharma, "Audit committee characteristics and investment in internal auditing", Journal of Accounting and Public Policy, vol. 29, no. 5, (2010), pp. 503-513.

[35] M. N. Mohamad-Nor, R. Shafie and W. N. Wan-Hussin, "Corporate governance and audit report lag in Malaysia", Asian Academy of Management Journal of Accounting and Finance, vol. 6, no. 2, (2010), pp. 57-84.

[36] M. Allegrini and G. Greco, "Corporate boards, audit committees and voluntary disclosure: evidence from Italian listed companies", Journal of Management and Governance, vol. 17, no. 1, (2013), pp. 187 216.

[37] H. Khlif and K. Samaha, "Internal control quality, Egyptian standards on auditing and external audit delays: evidence from the Egyptian Stock Exchange", International Journal of Auditing, vol. 18, no. 2, (2014), pp.139-154

[38] I. Karamanou and N. Vafeas, "The association between corporate boards, audit committees, and management earnings forecasts: an empirical analysis", Journal of Accounting Research, vol. 43, no. 3 , (2005), pp. 453-486.

[39] R. A. Rahman and F. H. M. Ali, "Board, audit committee, culture and earnings management: Malaysian evidence", Managerial Auditing Journal, vol. 21, no.7, (2006), pp. 783 - 804

[40] S. N. Bronson, J.V. Carcello, C.W. Hollingsworth and T.L. Neal, "Are fully independent audit committees really necessary?”,Journal of Accounting and Public Policy, vol. 28, no. 4, (2009), pp. 265280.

[41] King III, "King Report on Governance for South Africa", King Code of Governance Principles series, (2009).

[42] UK Code, UK Corporate Governance Code, FRC, London, (2010). 
[43] L.A. Jackson, D. Robinson and S.W. Shelton, "The Association between Audit Committee Characteristics, The Contracting Process and Fraudulent Financial Reporting" American Journal of Business, vol. 24, no. 1, (2009), pp. 57-65.

[44] Bapepam-LK, Keputusan Ketua BAPEPAM-LK nomor KEP-643/BL/2012 tentang Pembentukan dan Pedoman Pelaksanaan Kerja Komite Audit. Jakarta: Bapepam-LK, (2012).

[45] www.adb.org.,"Asean Corporate Governance Scoreca Country Reports And Assessments 2015 Joint Initiative Of The Asean Capital Markets Forum And The Asian Development Bank, (Retrieved, Dec. 9, 2017). (2017). 